\title{
Cuidado e Reconhecimento: categorias constitutivas do ser em uma via filosófica para o questionamento do suicídio através do campo da Narrativa e Medicina
}

\author{
Care and Recognition: constitutive categories of \\ being in a philosophical path for the questioning of \\ suicide through the field of Narrative Medicine
}

\author{
Rosely de FÁtima SiLVA* \\ VÂNIA de Oliveira Conzalezz**
}

\begin{abstract}
Resumo: A proposta deste artigo é analisar o suicídio como parte do elenco de ações humanas e, como tal, fruto de deliberação e reconhecido como uma ação do espectro ético humano, por meio das categorias do Cuidado (Sorge) heideggeriano e do Reconhecimento (anagnórisis) aristotélico, que são, em nossa visão, concomitantemente, hermenêuticas e ontológicas, e, como tais, essenciais ao campo da Narrativa e Medicina. Por meio dessas categorias, analisaremos o suicídio enquanto fenômeno de cisão ou não-cisão do ser. Auxiliar-nos-ão neste exercício algumas figuras paradigmáticas do herói grego, em particular Ájax e Édipo, e as repercussões desses personagens míticos em nossas concepções hodiernas sobre o suicídio.
\end{abstract}

Palavras-chave: cuidado, reconhecimento, suicídio, narrativa e medicina, ética, Aristóteles

Abstract: The proposal of this article is to analyze suicide among the set of human actions and, as so, recognize it as a consequence of deliberation and as an action among the human ethics spectrum, through the categories of Heidegger's care (Sorge) and Aristotle's recognition (anagnórisis), which are, in our view, both hermeneutic and ontological, and essential for the field of Narrative Medicine. Through these categories, we will analyze suicide whether being or not a phenomenon of the split of being. The paradigmatic figures of some Greek heroes, particularly Ajax and Oedipus, and the repercussion of these myths in our current conceptions about suicide will help us in this task.

Keywords: care, recognition, suicide, narrative medicine, ethics, Aristotle

\footnotetext{
Formada em Letras e Filosofia pela FFLCH-USP. Pós-Graduada em História da Filosofia Antiga pela mesma instituição.

** Fonoaudióloga formada pelo Depto. de Fisioterapia, Fonoaudiologia e Terapia Ocupacional da Faculdade de Medicina da Universidade de São Paulo. Graduada em Filosofia pela FFLCH-USP.
} 


\section{uidado: a versão heideggeriana}

Em seu tratado Ser e tempo (1927), Martin Heidegger retoma a fábula milenar do Cuidado, de origem latina e transmitida por Higino (séc. I d. C.).

Heidegger reinterpreta essa fábula, afirmando, em Ser e tempo, que "o ser-no-mundo [Dasein] é essencialmente Cuidado" (HEIDEGGER, 2012, p. 539, itálicos do autor). Na versão do filósofo alemão, o ser é fruto de um primeiro momento do pensamento do Cuidado que, ao atravessar um rio e ver o seu leito argiloso, resolve moldar o lodo; Júpiter aparece, e Cuidado lhe pede um espírito para o modelo. Nesse momento, uma discussão surge: qual deles possui o direito de nomear o ser criado? A Terra (Lodo) também entra na disputa. Saturno é nomeado o juiz, e

"profere a seguinte decisão equitativa: 'Tu, Júpiter, porque deste o espírito, deves recebê-lo na sua morte; tu, Terra, porque o presenteaste com o corpo, deves receber o corpo. Mas porque 'Cuidado' foi quem primeiro o formou, que ela então o possua enquanto ele viver. Mas, porque persiste a controvérsia sobre o nome, ele pode se chamar homo, pois é feito de húmus (terra)." (HEIDEGGER, 2012, p. 553)

Nesta leitura alegórica, Cuidado acompanha o homem durante toda a sua vida. Júpiter recebe o espírito após a morte, a Terra fica com o que lhe é de direito ("és pó, ao pó tornarás"...), e Saturno, divindade frequentemente associada ao tempo, é quem determina a existência do ser. Conclui-se, a partir disso, entre outros aspectos, que as ações do homem pontuam o tempo, dado que a sua existência nele está enraizada.

A fábula não é muito mais do que o que o filósofo reproduziu em sua obra, mas as notas que constam na sequência de seu texto elucidam, de certo modo, as interpretações e usos dados a ela e que, como o próprio Heidegger admite, influenciaram a escolha do termo Sorge para definir o Cuidado, em vez de escolher os termos Besorgnis ou Bekümmernis, respectivamente "inquietação" e "aflição".

Se, como afirma Heidegger, a leitura do artigo de K. Burdach, "Faust und die Sorge" (BURDACH, 1923), influenciou-o, de alguma maneira, em relação aos termos escolhidos para definir o Dasein, artigo esse que também ressalta a influên- 
cia do poema de Herder "Das Kind der Sorge" (O Filho do Cuidado) na elaboração do Quinto Ato do Fausto II de Goethe, faz-se necessário, aqui, um pequeno comentário sobre o modo como Sorge foi utilizado por esses autores e como essa plêiade pode ter influenciado o conceito de Sorge em Ser e tempo.

No poema de Herder, Sorge é, como na fábula de Higino, aquela entidade que acompanhará o homem enquanto ele viver. Em nossa tradução livre, Herder afirma, nos últimos versos do poema, que o Cuidado "é aquele que não se separará do homem, que o acompanhará em sua labuta diária até a morte".

Em Goethe (2007), Sorge aparece em contexto negativo, prenunciando a morte do centenário Fausto, personagem que tenta domar o tempo por meio do engenho humano. Fausto também é a representação do engenho humano em prol de um progresso inescrupuloso, que a tudo derruba; esse conceito de progresso, o domínio da vida pela técnica, faz-se necessário destacar, é algo que Heidegger veementemente deplorou. No episódio Mitternacht (Meia-noite) do Quinto Ato do Fausto II, quatro figuras femininas tentam adentrar os aposentos de Fausto: Penúria (Mangel), Insolvência (Schuld), Privação (Not) e Apreensão (Sorge). Apenas Sorge consegue entrar, enquanto, ao longe, outro irmão aproxima-se, Tod (em alemão, substantivo masculino), a Morte. Fausto pergunta: "Quem és tu?", e Sorge responde: "Bin einmal da", ou seja, "Sou quem está aí". Sua resposta não é uma qualificação ou uma descrição: sua resposta é "sou quem está aí", ou seja, estou aqui, em atividade, estou, neste momento, estou, como o ser no mundo, como o Dasein, em um modo infinitivo de existência, enquanto há existência, pois, como afirma a fábula, enquanto o homem viver, Sorge o acompanhará.

Ellis Dye comenta que

"Heidegger descreve a interpretação de Burdach sobre o Sorge no Fausto como pré-ontológica, isto é, como exibindo uma pré-concepção acrítica sobre aquilo a respeito de que se está perguntando. 'Cura' [termo presente na fábula de Higino], diz Burdach, é ambíguo, significando, por um lado, 'Sorge' [cuidado], 'Besorgnis' [preocupação], 'ängstliche Bemühung' [esforço angustiante] e, por outro, 'Sorgfalt' [cuidado], 'Hingabe' [dedicação], sentidos aos quais os verbos 'sich sorgen um' [preocupar-se com, inquietar-se com] e 'sorgen für' [cuidar de, tratar de] correspondem. Note-se o termo 'Seelsorger' - cuidador da alma - para pastor. Em Sêneca e Horácio, diz Burdach, Sorge é uma força construtiva - uma forma de 'Bemühung' [esforço, empenho] [...]. Mas em Fausto, como mostra Burdach, 
Sorge é algo mais elevado e mais nobre do que meramente 'strebendes Bemühen' (esforço ambicioso, aplicado); é essencialmente 'Fürsorge' ('preocupação com') ou solicitude ('sollicitudo')." (DYE, 2009, p. 208; trad. livre)

O que tentamos pontuar, portanto, e que acreditamos estar presente na prova pré-ontológica de Heidegger sobre o Dasein, é que, para ele, o Cuidado [Sorge] é essencialmente um processo, uma atividade constituinte do ser no mundo - como descreve a fábula de Higino -, e não um processo ou função externa à nossa existência que passivamente nos afeta.

No artigo "O cuidado, os modos de ser (do) humano e as práticas de saúde", José Ricardo de Carvalho Mesquita Ayres assim resume a importância da visão heideggeriana do Cuidado para a reconstrução ética, política e técnica do cuidado em saúde:

“Heidegger, especialmente em Ser e Tempo (1996), convida a pensar o modo de ser dos humanos como uma contínua concepção/realização de um projeto, a um só tempo determinado pelo contexto onde estão imersos, antes e para além de suas consciências, e aberto à capacidade de transcender essas contingências e, a partir delas e interagindo com elas, reconstruí-las. A temporalidade da existência, isto é, as experiências de passado, presente e futuro não são senão expressão desse estar projetado e projetando que marca esse modo de ser (do) humano - o futuro sendo sempre a continuidade do passado que se vê desde o presente, e o passado aquilo que virá a ser quando o futuro que vislumbramos se realizar. É isso que autoriza Heidegger, em Ser e Tempo, a nomear como Cuidado o ser do humano, numa referência a essa 'curadoria' que este está sempre exercendo sobre a sua própria existência e a do seu mundo, nunca como ato inteiramente consciente, intencional ou controlável, mas sempre como resultado de uma autocompre- ensão e ação transformadoras (Heidegger, 1995)". (AYRES, 2004, p. 21)

Ayres defende ainda, no mesmo artigo, que,

"se o ser do humano é um estar lançado no mundo, numa reconstrução constante de si mesmo e desse mundo, elucidada pela idéia de Cuidado, será justo assumir que as práticas de saúde, como parte desse estar lançado, tanto quanto dos movimentos que o reconstroem, também se elucidam como Cuidado. Também no 
plano operativo das práticas de saúde é possível designar por Cuidado uma atitude terapêutica que busque ativamente seu sentido existencial [...]". (AYRES, 2004, p. 22, itálicos nossos)

A partir dessa concepção heideggeriana sobre a ontologia do ser, ou seja: se, nas palavras de Heidegger, o fundamento ontológico do "ente que somos cada vez nós mesmos e que denominamos 'homem"' (HEIDEGGER, 2012, p. 549) reside no cuidado e, mais que isso, no cuidado de si e no cuidado-com-o-outro (HEIDEGGER, 2012, p. 539), como compreender, com base nisso, a deliberação de por fim à própria vida? Seria ela uma afirmação radical da liberdade de "poder-ser ele mesmo" (HEIDEGGER, 2012, p. 539), ou uma desistência completa da essência da sua própria humanidade enquanto ser-aí? Em outras palavras, trata-se de problematizar aqui, a partir da categoria heideggeriana de Cuidado, e de outras, a seguinte questão crucial: qual a dimensão existencial, no sentido fenomenológico do termo, dessa deliberação? E mais: haveria nela alguma ação "terapêutica", no sentido apontado por Ayres?

\section{O reconhecimento aristotélico}

Na Póetica ${ }^{1}$ (séc. IV a. C.), texto fundador das reflexões sobre as formas artísticas da linguagem e que esmiúça alguns de seus procedimentos formais, Aristóteles postula a categoria do reconhecimento ou anagnórisis como uma das técnicas ou estratégias mais eficazes utilizadas pelos poetas (termo que, à época, designava todo criador de linguagem com fins estéticos) para suscitar emoção. Sobre essa categoria, ele diz:

“O 'Reconhecimento', como indica o próprio significado da palavra, é a passagem do ignorar ao conhecer, que se faz para amizade ou inimizade das personagens que estão destinadas para a dita ou para a desdita.

1 ARISTÓTELES. Poética, IX, 1452a30-37, 1452b3-9. Dado o grande número de edições existentes das obras de filósofos antigos, para facilitar a consulta dos trechos citados neste artigo, colocaremos, além da referência constante no corpo do texto, para todos esses autores, em nota de rodapé, a localização standard, estabelecida pelos editores dos textos dos manuscritos originais. 
A mais bela de todas as formas de Reconhecimento é a que se dá justamente com a Peripécia, como por exemplo, no Édipo. E outras há ainda, referentes a objetos inanimados, quaisquer que sejam eles; e também constitui Reconhecimento o haver ou não haver praticado uma ação." (ARISTÓTELES, 1993, p. 61)

"[...] Posto que o Reconhecimento é reconhecimento de pessoas, pode acontecer que ele ocorra apenas numa pessoa a respeito da outra, quando uma das duas fica sabendo quem seja esta outra; noutros casos, ao invés, dá-se o Reconhecimento entre ambas as personagens. [...]" (ARISTÓTELES, 1993, p. 63)

O reconhecimento, em grego anagnórisis, é a ação e/ou efeito de voltar a conhecer. Nas tragédias gregas, por definição, é um elemento qualitativo, tão importante quanto a peripécia ou reviravolta, quando a trajetória dos heróis muda subitamente de rumo em função de algum elemento da ação.

As cenas de reconhecimento eram, e são ainda, pontos culminantes do mito nas narrativas épicas ${ }^{2}$ e trágicas. Uma de suas características estilísticas é a constituição, pelo poeta, no próprio texto poético, de um jogo de palavras que, enquanto envolve a audiência com recursos sonoros (aliterações, assonâncias) e semânticos (figuras, metáforas, etc.), aturde as personagens (e a audiência) na busca de si, ou seja, de um fio ou um sentido para a sua história. O comentário de Adriane da Silva Duarte elucida um pouco mais essa categoria:

"Além de ser um recurso estruturador da narrativa, capaz de promover o desenlace de um conflito e dotado de grande apelo emocional, sua vasta presença, igualmente atestada nos mitos, sugere que o reconhecimento seja antes uma resposta às inquietações do homem acerca de sua origem e de sua identidade." (DUARTE, 2012, p. 13)

2 Conquanto Aristóteles diferencie as artes miméticas (conf. Poética, 1448a 19-29) - dentre elas a Epopeia e a Tragédia - e considere que a forma narrativa não é característica da Tragédia e da Comédia, e sim da Epopeia, devido aos seus modos diversos de imitação - ou representação -, pois a Tragédia é uma imitação feita através de atores, diferentemente do que ocorre na Epopeia, consideramos aqui narrativa toda e qualquer produção - poética ou não - escrita na qual possamos encontrar elementos narrativos para análise. Interpretação semelhante encontramos na obra Tempo e Narrativa, de Paul Ricoeur, 1994, Tomo I, 65 e ss. 
Em relação à área da saúde, Carelli e Marques, em artigo de 2014, buscaram demonstrar a importância das categorias aristotélicas do reconhecimento e da peripécia na prática clínica:

“[Na composição da tragédia,] fatos ou condições 'ocultos', uma vez revelados, transformam mais ou menos radicalmente a história de vida dos envolvidos após tal 'reconhecimento'.

No campo da saúde, o mesmo pode ser dito a respeito da 'descoberta' de uma doença grave. Uma vez diagnosticada, a doença muda o curso da vida de um paciente de várias formas: tem o poder de mudar sua rotina (em outras palavras, os fatos e a cadeia dos fatos que constituem sua história [cotidiana]; introduz novos personagens na história; oferece, para seu desenvolvimento e desfecho, alternativas muito diferentes das previamente concebidas.

Assim, o fato ou condição antes [inexistente ou] desconhecidos e subitamente revelados obviamente modificam o futuro de uma história, ou seja, os eventos que sucederão após essa revelação. Ela promove, como diz Aristóteles, uma peripécia." (CARELLI, MARQUES, 2014, p. 48-9, itálico das autoras, trad. livre do original em inglês)

Um termo grego relacionado ao reconhecimento (anagnórisis), contudo embora não idêntico a ele, é anamnese. Na origem, a palavra tinha um significado inicial de recordação, e hodiernamente, na clínica médica, refere-se ao procedimento de levantamento e elaboração do histórico clínico de pacientes ("tirar a história"), por meio de entrevista realizada por médicos, ou profissionais de saúde em geral, a qual é institucionalmente limitada, restrita em quantidade específica de minutos pelas empresas de convênios privados de saúde e também pelo Sistema Único de Saúde brasileiro (SUS).

Apesar de tantas restrições protocolares, os momentos de anamnese clínica, em essência, promovem processos de (re)configuração narrativa das histórias de vida, e, deveriam, ao nosso ver e pelo exposto acima, ser considerados constitutivos por seus atores. Uma análise mais cuidada dos perfis e funções de três heróis gregos paradigmáticos nos auxiliará a compreender essa asserção: 


\section{1. Édipo, herói da responsabilidade}

A peça Édipo Rei, de Sófocles, é, para Aristóteles, paradigmática do elemento trágico do reconhecimento e seu exemplo mais perfeitamente acabado. Édipo é, ele mesmo, o herói do conhecimento, representação da racionalidade humana que se contrapõe à ordem cosmogônica e, portanto, está sujeito à punição, devido à hybris de sua busca. No entanto, Édipo suplanta, conquanto em meio ao sofrimento, a própria determinação que o oráculo - a linguagem - Ihe impõe. Como? Por meio do exercício constante da responsabilidade.

Como define Aristóteles, para que um agente moral seja considerado responsável por seus atos, primeiramente ele deve agir voluntariamente. Mas, para que o ato voluntário seja possível, o agente tem de ser o princípio da ação realizada e conhecedor das circunstâncias nas quais ela se dá. Atendidas essas condições, deve ainda o agente agir após deliberação racional. Com esses pressupostos, Édipo não pode ser considerado responsável pelo assassinato do pai, mas, apenas, pelo assassinato de um homem desconhecido, e, tampouco ser considerado responsável pelo casamento incestuoso com a mãe. Mas, ao tomar para si a responsabilidade que implica a construção do conhecimento do seu eu, torna-se um herói. Não só um herói paradigmático da responsabilidade, mas, além disso, herói da linguagem, decifrador de enigmas, e um anti-herói do conhecimento humano, um anti-herói no qual nos reconhecemos ${ }^{3}$.

Uma visão mais vertical desse herói trágico, no sentido da constituição da identidade, foi desenvolvida de outro modo por Paul Ricoeur em Tempo e narrativa (especialmente no volume I) (citaremos a partir da edição brasileira de 1994) e também em O si-mesmo como outro (2014). Em Tempo e narrativa, Ricoeur menciona o Édipo ao dissertar sobre o mythos (enredo, intriga) na Poética aristotélica, relevando os aspectos essenciais desse elemento trágico para Aristóteles. O comentário por ele realizado do texto da Poética tem, para Ricoeur, um objetivo declarado:

“A questão que não nos abandonará até o fim desta obra é a de saber se o paradigma de ordem, característico da tragédia, é suscetível de extensão e de transformação, a ponto de poder se aplicar ao conjunto do campo narrativo. [...] Assim, o muthos

3 Estes conceitos foram problematizados de forma mais compreensiva em SILVA, 2013. 
trágico eleva-se como a solução poética do paradoxo especulativo [agostiniano] do tempo, na própria medida em que a invenção da ordem é colocada, com exclusão de qualquer característica temporal." (RICOEUR, 1994, p. 65-6)

Com isso, Ricoeur quer dizer que a configuração do enredo do mythos trágico, para Aristóteles, substitui (momentaneamente) a aleatoriedade de eventos/ ações no tempo concreto da existência por uma relação de necessidade eminentemente narrativa e constitui, a partir do caos, uma lógica. Em outras palavras, o mythos trágico, em Aristóteles, teria a ver não com a dimensão da "vida", propriamente, mas com a da "obra":

“'Um todo, é dito, é o que tem um começo, um meio e um fim' (50b26). Ora, é somente em virtude da composição poética que algo vale como começo, como meio ou como fim [...]. A ênfase na análise dessa ideia de 'todo' é pois colocada na ausência do acaso e na conformidade às exigências de necessidade ou de probabilidade que organizam a sucessão. [...] [A]s ideias de começo, de meio e de fim não são extraídas da experiência: não são traços da ação efetiva, mas efeitos da ordenação do poema." (RICOEUR, 1994, p. 66-7)

É nessa altura da análise que Ricoeur, em Tempo e narrativa, cita o Édipo rei pela primeira vez, enfatizando a necessidade dos eventos narrados no mythos trágico, bem como a adequação da sua extensão no tempo da narrativa, sempre subordinada a um limite, pelo que alguns "tempos" (eventos) são excluídos, permanecem "vazios" (RICOEUR, 1994, p. 67).

Ricoeur volta ao Édipo ainda por três vezes nesse capítulo de Tempo e narrativa: primeiro, para enfatizar, com Aristóteles, a importância do reconhecimento e da peripécia nesse mythos/tragédia específicos, e, de modo inovador em relação ao texto clássico, para problematizar a noção de necessidade $x$ a ocorrência corriqueira do inesperado nas vivências "reais", cotidianas: "se a inversão [peripetéia] é tão essencial a qualquer história em que o insensato ameaça o sensato, a conjunção entre inversão e reconhecimento [anagnórisis] não conserva uma universalidade que ultrapassa o caso da tragédia?" (RICOEUR, 1994, 73-4). Em seguida, afirma o "potencial trágico" da tragédia (e da mímese) sobre a vida, potencial esse de uma "ética sobre a poética" (RICOEUR, 1994, p. 74 e 79), ou de aprendizagem e persuasão que vão do provável ao possível: "E onde esse 
trágico potencial é mais denso senão nas histórias recebidas relativas a algumas grandes casas célebres: os Átridas, Édipo e os seus...?" (RICOEUR, 1994, p. 79). Por fim, enfatiza a aprendizagem engendrada pela categoria do reconhecimento, mencionando o Édipo como exemplo: "O prazer de aprender é, pois, o de reconhecer. É o que faz o espectador, quando reconhece no Édipo o universal que a intriga engendra apenas por sua composição" (RICOEUR, 1994, p. 81).

À volta à "vida" dessa organização narrativa do mythos, ou seja, "extrair as implicações temporais do modelo [aristotélico]", constituirá a "tarefa e responsabilidade" (RICOEUR, 1994, p. 66) declaradas do filósofo francês ao longo dos três volumes de Tempo e narrativa. Por ora, é importante enfatizar que, para ele, o aspecto ético dessa poética está muito mais ligado à organização das ações no enredo do que propriamente na caracterização dos heróis trágicos, tal como vimos desenvolvendo aqui.

Em O si-mesmo como outro, obra dedicada justamente à questão da construção identitária do si a partir da narrativa, a posição de Ricoeur fica ainda mais clara. Nesse livro, dito de modo bem simplificado, o filósofo francês postula que nenhum ser humano, apesar de constantemente constrangido pela noção de possuir uma identidade permanente no tempo (mesmo nome, registro civil, laços familiares, características corporais e de personalidade a si atribuídas), permanece o mesmo toda a vida: "A identidade, no sentido de idem, [...] apresenta uma hierarquia de significados [...] cujo grau mais elevado constitui a permanência no tempo; a ele se opõe o diferente, no sentido de mutável, variável" (RICOEUR, 2014, p. XIII). Para fazer frente a esse tipo de configuração da identidade, o filósofo propõe o que chama de "identidade ipse", uma identidade que implica a alteridade e, às asserções do "mesmo", propõe as noções de "outro", "contrário", "distinto", "diverso" (RICOEUR, 2014, p. XIV). Para ele, a dialética entre mesmo e outro corresponde, no tempo, à configuração de uma "identidade narrativa" (RICOEUR, 2014, passim).

Para discutir a possibilidade de um ensinamento ético por meio da tragédia, a exemplo de Hegel, Ricoeur preterirá, nesse livro, a peça Édipo Rei em função de Antígona, afirmando que o efeito poderoso da tragédia enquanto gênero está, entre outros, na sua "mistura indecomponível de coerções ditadas pelo destino e de escolhas deliberadas" (RICOEUR, 2014, p. 279). Mas opõe-se a Aristóteles e a Kant, afirmando que a determinação prática da ação ética, na tragédia, "não se deixa reduzir a uma simples modalidade da escolha e da deliberação" (RICOEUR, 
2014, p. 278), uma vez que não há deliberação humana possível que liberte o homem da intervenção do imponderável, representada, no texto trágico, pela força da determinação divina. Nesse sentido, afirma Ricoeur, "uma das funções da tragédia em relação à ética é criar uma distância entre sabedoria trágica e sabedoria prática" (RICOEUR, 2014, p. 284), afirmando o papel inevitável do conflito na vida prática no sentido da constituição de uma identidade narrativa que se constrói a partir das ruínas do conformismo e da arbitrariedade de leis e regras externas ao homem.

Assim, voltando ao Édipo, podemos dizer que, no texto trágico de Sófocles, destruída a identidade "idem" do herói por meio dos momentos de anagnórisis e, portanto, das inúmeras identidades "ipse" que lhe são arroladas, constituem-se suas identidades narrativas, paroxismos do "si-mesmo como outro(s)", processo de re-conhecimento que Édipo não mais abandonará, como descreve o mito. Muito embora as previsões do oráculo tenham se concretizado, ele permanece o herói da deliberação e da valorização do conhecimento por meio do qual aflora a sua hybris, conhecimento esse que se revela, desafortunadamente, demasiadamente humano. O imperativo categórico edipiano é o conhecer, nele incluso todo o espectro de responsabilidade da ação moral. Sua tragédia consuma-se ao reconhecer-se nos relatos que descrevem a trajetória do filho de Laio e Jocasta, nos relatos que descrevem a ação do assassino de Laio, nas narrativas coincidentes do oráculo outrora por ele consultado e confirmadas pelas palavras de Tirésias. O seu reconhecimento é destruição que leva à construção de um outro Édipo, que ainda é o mesmo, mas narrado de outro modo: não mais o melhor dos homens, mas o homem que melhor assinala a condição errática do humano.

A narrativa edipiana apresenta-se, assim, como um caleidoscópio hermenêutico e metafórico para a mímesis ricoeuriana, na qual os elementos de pré-figuração, configuração e re-figuração são continuamente transladados de suas posições, pois, no interior da própria narrativa, a personagem percorre os três tempos miméticos, na busca de um voltar a conhecer(-se). Édipo é o herói que nos convida ao exercício de busca e de reconfiguração narrativa: ele não se retira da existência, re-narra-se. 
Semelhantemente, na configuração das anamneses clínicas, acreditamos, há essa reconstrução narrativa do ser ${ }^{4}$.

\section{2. Ájax: o paradigma do herói suicida}

Todo herói grego busca permanentemente a kleos (ou glória) póstuma, sempre a brilhar. Porém, nessa busca, há a necessidade de não ultrapassar a medida. Aquiles optou abandonar uma longa vida terrena em prol da memória eterna. As armas de Aquiles, o melhor dos aqueus, divino presente e prêmio para os melhores guerreiros que a ele sobreviveram, não parecem ser passíveis de utilização pelos demais homens. Elas se configuram, enquanto objetos, como receptáculos da morte, antes que da glória. Aqueles que as utilizaram, como vestimentas miasmáticas, também por elas foram destruídos, como Pátroclo, Heitor e aqueles que as desejaram ou receberam, Ájax e Odisseus, que, se morto não foi, muito tardou a retornar ao lar. Se as armas identificam o herói, ao matar Heitor, que tomara as vestes aquilianas do corpo de Pátroclo, Aquiles sabia que, em verdade, matava a si.

Três situações são dignas de destaque, na tragédia de Ájax: a primeira, a matança do rebanho, à noite, que acreditava serem seus inimigos atridas, e que os comentadores do texto trágico chamam de "ação dolosa do herói"; a segunda, a ação dolosa de Atena sobre a mētis (sabedoria, discernimento) do herói, que provocou, em parte, a ação anteriormente citada, e, por fim, a resolução suicida de Ájax. Todas estas ações envolvem a des-configuração da mētis.

Preterido na escolha das armas de Aquiles, Ájax delibera vingar-se dos líderes argivos e de Odisseus. Operando na chave de seu oponente, usa do ludibrio para se acercar das tendas de seus inimigos, e da noite para encobrir a sua ação. Mas esta não é a sua natureza, e Atena, deusa da mētis e aliada de Odisseus, desvia-lhe a mente e as mãos para o massacre do rebanho.

O reconhecimento das reais ações que perpetrou, a vinculação de sua figura heróica ao rebanho dizimado, vítimas imbeles de sua insânia e de seu furor, le-

4 Não ao acaso, Carelli e Marques também consideram, no artigo já citado aqui, o caráter ético e prático do Édipo Rei na reconfiguração das narrativas clínicas e na proposta de uma ação clínica propriamente narrativa (CARELLI, MARQUES, 2014, p. 48-50). 
vam Ájax a compreender que, enquanto herói, ele não mais é. Apátrida dos seus, apátrida de si, decide morrer em terra estrangeira, unindo-se ao inimigo troiano, pela última vez, tornando-o amigo através da lâmina - outrora de Heitor - que Ihe cinde a vida, posto que a sua auto avaliação ôntica já se encontra cindida. Atingido pela deusa e pelo herói polymētis, percorre um esboço da via polymétis típica de Atena e de Odisseus, ao conceber a realização de seu suicídio. Palavras de plácida conciliação com o status quo saem de sua boca, mas o herói solitário não mudou a sua natureza; ele ainda é um gigante, deslocado entre os seus.

Além do conflito ético do herói, um conflito civilizatório se apresenta na tragédia: de um lado, temos a visão idealizada que o herói possui de si, versus as restrições impostas pelo mundo dos homens e pelo ordenamento cosmogônico dos deuses. Ájax é, a um só tempo, um herói afastado da comunidade humana, dos seus costumes e valores, e um alijado dos deuses.

A violência emblemática das tragédias é o que Segal classifica como

"a solução grega para o problema da civilização, a ritualização da violência e da agressão [...]. Nessa perspectiva, uma das grandes conquistas do século $V$ seria a criação de uma forma que sublima à categoria da arte mais elevada a confrontação humana mais acre e dolorosa com sua própria selvageria." (SEGAL, 1981, p. 7; trad. livre)

O herói grego é o paradigma de um homem localizado entre os deuses e as bestas, do conflito oriundo do estabelecimento da civilização, civilização essa que se contrapõe tanto à ordem divina, quanto à aceitação do caos, resultando desse conflito os principais questionamentos sobre a existência humana presente nas tragédias gregas.

Para Ájax, ir contra a própria natureza do herói é reconhecer as limitações e os cerceamentos morais e políticos de sua constituição humana e de sua singularidade heroica, daí a sua intransponível dor, que acarreta a sua ruína, a derrisão de sua função de líder em sua comunidade e, consequentemente, a sua eliminação pelo suicídio:

"O que se pede que o herói faça, a demanda por trás do apelo à razão e da emoção, o convite à reflexão e a ser persuadido - é desistir [eikeiv]. Esta palavra (com suas derivadas) é a chave para a situação trágica de Sófocles: ela aparece em todas as 
suas seis peças no contexto significante do ataque à resolução do herói." (KNOX, 1966, p. 15; trad. livre)

Ainda segundo Knox, a condenação do caráter heroico de Ájax é tanto moral quanto intelectual. Diferentemente de seu opositor, Odisseus, o herói polymētis [multi-astucioso, engenhoso], Ájax é carregado de aphrosynē [insensatez], é sem senso, anous.

Para Ájax, é eticamente impossível viver sem ser reconhecido pelos seus, como ele próprio se reconhece: impossível considerar-se polutos, miasmático, como a comunidade comandada pelos atridas o julga. Ájax, que não é um herói que ceda às pressões da comuna ou da razão - e portanto, não é amparado por ela, para, ato contínuo, suplantá-la, como Édipo -, só encontra solução para o seu dilema eliminando o que o gerou: o seu próprio ser. Nele, não há metron, tampouco a mediedade proposta por Aristóteles para a ação humana. Se o homem se constitui no tempo, Ájax, ao contrário, prefere elidir-se do mundo, calcina a sua existência e as suas dores por meio do suicídio. Não lhe parece uma alternativa viável percorrer a existência em um mundo que tenta mitigá-lo, - como ocorre a Édipo -, para transpô-lo, por fim, em uma ascensio do estado humano para o divino, como se supõe ao final do Édipo em Colono.

O suicídio de Ájax, e o seu desafio a kronos, poderiam ser considerados uma pergunta metafísica a respeito do que está para além do tempo e do que é, enquanto é, existindo desde sempre? Se a kleos reconhecida é o único modo de sermos imortais, enquanto homens, destruir esta forma que nos compõe jungida a esta matéria em ato é uma possibilidade ética? Ou apenas o signo de uma derrota?

Para o herói sofocliano, "a opinião dos outros é irrelevante. Sua lealdade à sua concepção de si mesmo e a necessidade de executar a ação que tal concepção impõe, prevalecem sobre todas as outras considerações" (KNOX, 1966, p. 28; trad. livre).

Se consideramos que agimos corretamente, nada mais ético do que agirmos conforme esta consciência. O paroxismo das ações de Édipo e Ájax derivam des- 
ta assunção. Mas, para além da ação individual, o conceito de eudaimonia ${ }^{5}$ aristotélica vincula-se à realização ética do indivíduo junto à polis. E é justamente este o ponto no qual Odisseus supera Ájax, enquanto paradigma do herói, no contexto ateniense: suas ações, obradas racionalmente, operam em favor da comunidade.

A ação final de Ájax, o suicídio, encontra, em Platão, três plausibilidades:

"Quem mata o mais próximo e se diz ser o mais amado de todos, que punição deve sofrer? Refiro-me a quem se mata a si mesmo, impedindo com violência o cumprimento de seu destino, sem que isso Ihe seja ordenado judicialmente pela cidade, nem forçado por má sorte que o houvesse tocado com dor excessiva e inevitável, ou porque o aflija uma vergonha que ponha sua vida em um beco sem saída e torne-a impossível de ser vivida, mas, sim, aplicando eventualmente um castigo injusto a si mesmo, por preguiça e covardia próprias da falta de hombridade." (PLATÃO, 1999, p. 167-168; trad. livre do espanhol) ${ }^{6}$

Ou seja, o suicida teria seu ato justificado se uma grande dor o tocasse, uma desonra lhe desfigurasse o èthos, ou se isso fosse uma prerrogativa das leis da polis. Ressalte-se o destaque ao amor próprio que Platão faz.

Aristóteles reforça tais argumentos, asseverando que o suicida não prejudica a si, mas à cidade ${ }^{7}$ (ARISTÓTELES, 1988, p. 264-265). Age, sim, contra a razão, e voluntariamente; no entanto, não comete injustiça contra si, pois não seria possível, voluntariamente, sofrer uma injustiça.

Ainda no Livro III da Ethica Nicomachea, lemos:

5 Comenta Silva (2013, p. 15-6): “a eudaimonia é o maior bem, pois, uma vez obtida, nada mais é necessário, ela é o que se busca por ela mesma; e assim como a felicidade suprema é autossuficiente, o homem que a alcança também o é. Ross (1953, p. 190) comenta que o termo bem-estar, por ser mais vago, é melhor tradução para eudaimonia que felicidade, visto que eudaimonia está vinculada à ação, e felicidade é, antes, um estado de sentimento; consideramos, no entanto, que esta posição de Ross, apesar de contemplar a defesa de Aristóteles de que a felicidade é uma atividade, também está permeada de alguma indeterminação; se traduzirmos, ao pé-da-letra, well-being por bem estando, o que, em nossa língua, soaria esdrúxulo, ao menos nos aproximaríamos da noção de atividade contínua que consta no conceito de felicidade aristotélica. Como inúmeros termos gregos, a melhor escolha é não traduzi-los."

6 PLATÃO. Leis. IX, 873c2-d1.

7 ARISTÓTELES. Ethica Nicomachea, V, 1138a4 e ss. 
A bravura é termo médio em relação às coisas que inspiram confiança ou medo e, em situações estabelecidas, elege e suporta o perigo porque é honrado fazêlo assim, e vergonhoso não fazê-lo. Mas morrer para evitar a pobreza, o amor ou algo doloroso não é proprio do valente, mas do covarde; porque é suavidade evitar o penoso, e não sofre a morte por ser nobre, mas, sim, para evitar um mal." (ARISTÓTELES, 1988, p. 196)

A despeito do trecho platônico citado acima, há uma dicotomia entre as proposições do mito presentes no teatro grego, representadas por seus heróis singulares, e as proposições dos filósofos da nova era política ateniense, cujas diferenças estruturais corroboram a valorização da vida em comunidade, política, na polis. Assim, tanto Platão quanto Aristóteles, embora apresentem situações em que o suicídio seria aceitável, ainda o consideram um ato prejudicial à comunidade (visão aristotélica), ou acintoso à divindade (visão platônica), e, portanto, proibitivo. Como bem salienta Fernando Rey Puente:

Argumentos contrários ao suicídio e favoráveis a ele (na maioria das vezes favoráveis em circunstâncias específicas) foram bem explicitados desde a Antiguidade. Se a vida não nos pertence, se não escolhemos o momento de nascer, o que nos autorizaria então deixá-la quando assim deliberássemos? A metáfora da sentinela que se encontra em seu posto e não pode abandoná-lo sem uma autorização superior da divindade (presente em Platão, mas de origem pitagórica), bem como o argumento complementar, igualmente presente no Fédon, segundo o qual a vida não nos pertence, mas sim à divindade que no-la concedeu, perfez uma longa trajetória durante a qual se cristianizou (como se depreende da obra de Agostinho ou do texto de Tomás de Aquino [...] e que sintetiza os argumentos principais enumerados pelo bispo de Hipona)." (PUENTE, 2008, p. 10)

É defensável e totalmente aceitável que o homem se realize individualmente, em termos éticos, em prol de uma sociedade da qual ele é um constituinte e que Ihe garantirá a existência e a de seus compatriotas, e que essa realização individual seja preconizada como concomitante com a realização política dos demais cidadãos. Mas tal realização parece-nos uma utopia. No entanto, essa utopia é a base das sociedades de origem eurocêntrica: na encruzilhada entre a sociedade 
e o pensamento filosófico, qual seria o papel da produção poética, mais especificamente da tragédia? Conforme Euben,

Colocar o assunto desta forma sugere que a tragédia possa ser radical, crítica e autocrítica porque era conservadora. Como ato comunitário e parte de um festival religioso, a tragédia reafirmava as tradições políticas da cidade, seus rituais e deuses. Mas isso não levava os poetas trágicos a aceitar acriticamente o contexto que fazia a performance das suas peças plausível. Pelo contrario, a tragédia explorava as paixões e ações que nenhuma vida pública podia conter, e problematizava as acomodações culturais mais fundamentais da cidade, fossem essas sexuais, geracionais, institucionais ou intelectuais. Esse paradoxo encontra paralelos na situação do herói trágico que é, ao mesmo tempo, um libertador/ criador e uma ameaça/um destruidor de sua comunidade. Uma ambivalência similar se aplica aos poetas trágicos e aos teóricos políticos." (EUBEN, 1986, p. 27)

A relevância da análise da figura do herói trágico frente à Ética pode ser entendida pelas palavras de Segal: "Seus sofrimentos compreendem uma jornada metafórica e, por vezes, literal aos limites da experiência humana, e além" (SE$\mathrm{GAL}, 1981$, p. 11).

Estabelecida a existência do conflito da própria existência humana, qual a via que escolheremos para a compreensão de sua manutenção, ou, no outro extremo, da sua extinção voluntária pela via do suicídio? A via edipiana, da re-configuração narrativa, ou de Ájax, da elisão temporal e, portanto, existencial, ambas vinculadas à categoria do reconhecimento? Ou a via heideggeriana, de reconstituição e permanência pela categoria do Cuidado?

\section{Camus e o suicídio: a existência como a via do absurdo}

Dissemos acima, após a análise das figuras heroicas Édipo e de Ájax, que, se consideramos que agimos corretamente, nada mais ético do que agirmos conforme essa consciência. Esse é um truísmo constante nas discussões sobre o suicídio, como se vê no início do ensaio de Camus, O Mito de Sísifo: 
“O assunto deste ensaio é precisamente essa relação entre o absurdo e o suicídio, a medida exata em que o suicídio é uma solução para o absurdo. Pode-se tomar por princípio que, para um homem que não trapaceia, o que ele acredita verdadeiro deve pautar a ação. A crença na absurdidade da existência deve, pois, Ihe dirigir o comportamento. É uma curiosidade legítima se indagar claramente, e sem falso pateticismo, se uma conclusão de tal ordem exige que se abandone o mais que depressa uma condição incompreensível. Refiro-me aqui, é claro, a homens dispostos a estarem de acordo consigo mesmos." (CAMUS, 1989, p. 26)

Ao lermos essas palavras, tendemos a crer que Camus fará uma franca defesa do ato suicida. No entanto, utilizando uma escrita magistral, ele operará a adesão do homem à vida por meio de uma via hermenêutica de apreensão do absurdo de nossa existência.

Não é difícil concordarmos com Camus de que "... se trata, para começar, da relação entre o pensamento individual e o suicídio", de que um "gesto como este se prepara no silêncio do coração, da mesma forma que uma grande obra" (CAMUS, 1942, p. 24). Como se depreende da leitura da peça de Sófocles, mesmo em seu contexto clássico (no qual a noção de subjetividade ainda não está constituída social e teoricamente), Ájax delibera "no silêncio do coração". No entanto, curiosa ou paradoxalmente, o escritor franco-argelino afasta de sua tipificação do suicídio o caráter de fenômeno social: para ele, "começar a pensar é começar a ser minado. A sociedade não tem muito a ver com esses começos. O verme se acha no coração do homem" (CAMUS, 1942, p. 24). Parcialmente discordamos do autor franco-argelino, pois, se o suicídio é fruto de uma deliberação individual, muitas vezes essa deliberação torna-se ato pela premência de nosso entorno social, de nossas relações. Assim, corroboramos os assentamentos de Marx sobre o tema, na obra Sobre o Suicídio, em que traduz e comenta um texto de memórias de um antigo diretor dos Arquivos da Polícia, do período da Restauração Francesa, Jacques Peuchet:

"Que tipo de sociedade é esta, em que se encontra a mais profunda solidão no seio de tantos milhões; em que se pode ser tomado por um desejo implacável de matar a si mesmo, sem que ninguém possa prevê-lo? Tal sociedade não é uma sociedade; ela é, como diz Rousseau, uma selva, habitada por feras selvagens. [...] Entre as causas do desespero que levam as pessoas muito nervosas-irritáveis a buscar a 
morte, seres passionais e melancólicos, descobri os maus-tratos como o fator dominante, as injustiças, os castigos secretos, que pais e superiores impiedosos infligem às pessoas que se encontram sob sua dependência. A Revolução não derrubou todas as tiranias; os males que se reprovavam nos poderes despóticos subsistem nas famílias; nelas eles provocam crises análogas àquelas das revoluções. [...] As relações entre os interesses e os ânimos, as verdadeiras relações entre os indivíduos ainda estão para ser criadas entre nós inteiramente, e o suicídio não é mais do que um entre mil e um sintomas da luta social geral, sempre percebida em fatos recentes, da qual tantos combatentes se retiram porque estão cansados de serem contados entre as vítimas ou porque se insurgem contra a ideia de assumir um lugar honroso entre os carrascos." (MARX, 2006, p. 28-9)

Entretanto, o próprio Camus faz uma descrição da vida - em sociedade - $a b$ surda:

"Ocorre que os cenários se desmoronam. Levantar-se, bonde, quatro horas de escritório ou fábrica, refeição, bonde, quatro horas de trabalho, refeição, sono, e segunda, terça, quarta, quinta, sexta e sábado no mesmo ritmo, essa estrada se sucede facilmente a maior parte do tempo. Um dia apenas o 'porquê' desponta e tudo começa com esse cansaço tingido de espanto. 'Começa', isso é importante. O cansaço está no final dos atos de uma vida mecânica, mas inaugura ao mesmo tempo o movimento da consciência [grifo nosso]. Ele a desperta e desafia a continuação. A continuação é o retorno inconsciente à mesma trama ou o despertar definitivo. No extremo do despertar vem, com o tempo, a consequência: suicídio ou restabelecimento. [...] por ora isso é suficiente para a oportunidade de um reconhecimento sumário das origens do absurdo. A simples 'preocupação' está na origem de tudo.

Da mesma forma, e ao longo de todos os dias de uma vida sem brilho, o tempo nos carrega. Mas sempre chega um momento em que é preciso carregá-lo. Vivemos para o futuro: 'amanhã', 'mais tarde', 'quando você tiver uma situação', 'com o tempo você vai compreender'. Essas inconsequências são admiráveis porque, afinal, se trata de morrer. Mas chega um dia e o homem verifica ou diz que tem trinta anos. Afirma assim sua juventude. Mas, nesse mesmo lance, se situa com relação ao tempo. Ocupa ali seu lugar. Reconhece que está num dado momento de uma curva que confessa ter de percorrer. Ele pertence ao tempo e, nesse horror 
que o agarra, reconhece nele seu pior inimigo. Amanhã, ele queria tanto amanhã, quando ele próprio deveria ter-se recusado inteiramente a isso. Essa revolta da carne é o absurdo." (CAMUS, 1989, p. 32-3)

Camus pontua que a descrição acima não se trata, porém, de uma definição do absurdo, mas de uma enumeração de como ele se dá. O ensaio é longo e possui muitas digressões que não podem ser desenvolvidas no espaço deste artigo. Tentemos, assim, destacar os pontos que consideramos essenciais para uma hermenêutica existencial. São eles: a vida é absurda, portanto, destituída de sentido; no entanto, a consciência desse absurdo nos faz prescindir tanto da necessidade de explicações metafísicas para justificarmos estarmos vivos o que Camus denomina de nostalgia do absoluto -, quanto da adesão a um niilismo irracional. Entende-se, assim, o absurdo como um deserto que não se deve deixar, porque é nele que se dará a consciência do que consiste a nossa existência:

"[...] o homem se vê diante do irracional. Sente dentro de si o desejo de felicidade e de razão. O absurdo nasce desse confronto entre o apelo humano e o silêncio despropositado do mundo. É isso que não se deve esquecer. É a isso que é preciso se agarrar, pois toda a consequência de uma vida pode nascer daí. O irracional, a nostalgia humana, o absurdo que surge do diálogo entre eles: eis os três personagens do drama que deve necessariamente, acabar com toda a lógica de que uma existência é capaz." (CAMUS, 1989, p. 46)

O autor considera que a aceitação do absurdo elimina a possibilidade do suicídio, pois, o suicida, ao seu modo, ao morrer, resolve o absurdo, e o absurdo não pode se resolver. Camus é um tanto sofista, assim pensamos, neste e em outros trechos de seu ensaio, quando, por exemplo, conclui que "a crença no absurdo passa a substituir a qualidade das experiências pela quantidade" (CAMUS, 1989, p. 77), dada à limitação temporal inerente às nossas vidas. Assim, utiliza o exemplo do ator para ilustrar a sua posição: "Para o ator, como para o homem absurdo, uma morte prematura é irreparável" (CAMUS, 1989, p. 103). No entanto, suas proposições em prol de uma postura filosófica que una revolta e consciência nos parecem frutíferas. 
Para corroborar a sua argumentação, no capítulo final do ensaio, analisa os mitos de Sísifo e de Édipo. Sísifo é assim definido:

[...] Sísifo é o herói absurdo. Ele o é tanto por suas paixões como por seu tormento. $\mathrm{O}$ desprezo pelos deuses, o ódio à Morte e a paixão pela vida Ihe valeram esse suplício indescritível em que todo o ser se ocupa em não completar nada. [...] Se esse mito é trágico, é que seu herói é consciente. Onde estaria, de fato, a sua pena, se a cada passo o sustentasse a esperança de ser bem-sucedido? O operário de hoje trabalha todos os dias de sua vida nas mesmas tarefas e esse destino não é menos absurdo. Mas ele só é trágico nos raros momentos em que se torna consciente. Sísifo, proletário dos deuses, impotente e revoltado, conhece toda a extensão de sua condição miserável: é nela que ele pensa enquanto desce. A lucidez que devia produzir o seu tormento consome, com a mesma força, sua vitória. Não existe destino que não se supere pelo desprezo. (CAMUS, 1989, p. 142-3)

É digno de nota lembrarmos, ainda, que o mito possui uma variante, na qual Sísifo acorrenta a Morte (!).

A conclusão de Camus sobre Édipo corrobora a nossa: ele é o herói do conhecimento, e opta por não se elidir do tempo; nele estão presentes a consciência e a revolta. E, paradoxalmente, na construção desse conhecimento, haveria traços de felicidade:

"[...] Édipo de início obedece ao destino sem o saber. A partir do momento em que ele sabe, sua tragédia principia. Mas no mesmo instante, cego e desesperado, reconhece que o único laço que o prende ao mundo é o frescor da mão de uma garota. Uma fala descomedida ressoa então: 'Apesar de tantas experiências, minha idade avançada e a grandeza da minha alma me fazem achar que tudo está bem.'[...] 'Acho que está tudo bem', diz Édipo, e essa fala é sagrada. Ela ressoa no universo feroz e limitado do homem. Ensina que tudo não é e não foi esgotado. Expulsa deste mundo um deus que nele havia entrado com a insatisfação e o gosto pelas dores inúteis. Faz do destino um assunto do homem e que deve ser acertado entre os homens." (CAMUS, 1989, p. 144)

Ao final da leitura de seu ensaio, talvez coubesse perguntar: haveria Camus construído uma metafísica do absurdo? Como Sísifo, retomaremos literalmente 
a questão posta acima: estabelecida a existência do conflito da própria existência humana, qual a via que escolheremos para a compreensão de sua manutenção, ou, no outro extremo, da sua extinção voluntária pela via do suicídio? A via edipiana, da re-configuração narrativa, ou de Ájax, da elisão temporal e, portanto, existencial, ambas vinculadas à categoria do reconhecimento? $\mathrm{Ou}$ a via heideggeriana, de reconstituição e permanência pela categoria do Cuidado? Ou mesmo a via de Camus, de aderência ao absurdo?

\section{Possibilidades da via filosófica para a compreensão do topos do suicídio}

Sobre o suicídio, nos disse Sêneca:

"17 Queres ser desprendido em relação a esse corpo? Habita-o tal qual alguém que está prestes a se mudar. Tem consciência clara de que um dia deverá abster-te desse convívio: estarás mais forte para quando chegar o momento de abandonálo. Mas de que maneira o próprio fim virá à mente daqueles que cobiçam todas as coisas sem fim? 18 A reflexão sobre nenhum assunto é tão necessária quanto essa; talvez, as demais discussões sejam realizadas em vão." ${ }^{8}$ (SÊNECA, apud PUENTE, 2008, p. 71; itálicos nossos)

É quase indubitável que Camus glosou Sêneca ao dizer, no início do ensaio que comentamos acima: "Só existe um problema filosófico verdadeiramente sério: o suicídio. Julgar se a vida vale ou não vale a pena ser vivida é responder a questão fundamental da filosofia" (CAMUS, 1989, p. 23). Mas, diferentemente do filósofo que glosou, como percebemos, Camus não é um defensor sequer parcial da prática do suicídio, pois o considera não um ato de consciência e revolta perante o absurdo que constitui a nossa existência, mas um assentimento, ou seja, uma passividade perante à vida.

Sabemos também que as concepções platônicas e aristotélicas foram aditadas às concepções de e por filósofos cristãos como Agostinho e, posteriormente,

8 SÊNECA, Lúcio Aneu. Epístolas a Lucíolo, VIII, epístola 70. Tradução de Sandra Maria Gualberto Braga Bianchet. 
Tomás de Aquino. Tais aditamentos foram analisados e criticados, posteriormente, por Rousseau e Hume ${ }^{9}$, dentre outros filósofos, e questionou-se o porquê da interdição do suicídio pela Igreja, dado que não há, nos textos bíblicos, condenação explícita de tal ato. Para os defensores de tal posição, cita-se, como exemplo, Sansão, cuja morte de si é um ato deliberado e consciente executado em benefício de sua comunidade.

Hume retoma a metáfora platônica da sentinela, bem como o questionamento aristotélico sobre o dano que a morte de si causa à comunidade:

"Mas você é colocado pela providência, como uma sentinela numa estação particular e, quando você a deserta, sem ter sido convocado, é culpado de rebelião contra seu soberano todo-poderoso, e terá incorrido em seu desprazer.

Pergunto, o que o leva a concluir que a providência me colocou nesta estação? Da minha parte, considero que devo meu nascimento a uma longa cadeia de causas, muitas das quais dependem das ações voluntárias dos homens. Mas a providência guiou todas essas causas, e nada ocorre no universo sem o seu consentimento e cooperação. Se for assim, então também minha morte, embora voluntária, não acontece sem o seu consentimento; e se a dor ou pesar superam minha paciência ao ponto de me deixarem cansado da vida, posso concluir que estou sendo convocado de minha estação, nos termos mais claros e expressos. Foi certamente a providência que me colocou no momento presente neste aposento. Mas eu não posso sair dele, quando considero apropriado, sem por isso incorrer na imputação de ter deserdado meu posto ou estação? Quando estiver morto, os princípios de que sou composto ainda desempenharão sua parte no universo e serão igualmente úteis na grande trama, do mesmo modo como quando compuseram esta criatura individual. A diferença não será maior para o todo do que a que há entre encontrarme no interior de um aposento ou ao ar livre. Uma mudança é mais importante para mim do que a outra, mas não para o universo." (HUME, apud PUENTE, 2008, p. 117-8)

9 “Um ganho considerável que se tem com a filosofia é o supremo antídoto que fornece contra a superstição e a falsa religião." Assim o filósofo inicia o seu ensaio Do Suicídio, obra de publicação póstuma: dada a controvérsia ocorrida da leitura das provas, Hume e o seu editor houveram por bem retirá-lo da edição final do volume em que estava incluído. 
"[...] Um homem que se retira da vida não prejudica a sociedade. Ele apenas deixa de fazer o bem - o que, se for uma injúria, é uma das menores." ${ }^{10}$ (HUME, apud PUENTE, 2008, p. 119)

Rousseau, no romance epistolar A Nova Heloísa, através das cartas trocadas entre as personagens Saint-Preux e Bomston, apresenta argumentos pró e contra o suicídio e, como Hume, retoma as metáforas platônicas. Assim, Saint-Preux, dirigindo-se Edouard Bomston, inicia o desenvolvimento da argumentação:

“[...] procurar o próprio bem e fugir do próprio mal naquilo que não ofenda o outro, este é o direito da natureza. Quando nossa vida é um mal para nós e não é um bem para ninguém, é então permitido dela se livrar.

[...] Que dizem disso nossos sofistas? Primeiramente, consideram a vida como algo que não é nosso, porque ela nos foi dada; mas é precisamente porque ela nos foi dada que ela é nossa. Deus não Ihes deu dois braços? Porém, quando eles temem a gangrena, eles Ihes cortam um ou todos os dois braços, se for preciso.

[...] Mas você mesmo, ele o colocou na sua cidade; por que sair dela sem sua licença? A licença não está no mal estar? Em qualquer lugar que ele me colocar, seja em corpo, seja na terra, é para eu ficar ali enquanto estiver bem, e para dali sair quando estiver mal."11 (ROUSSEAU, apud PUENTE, 2008, p. 126-7)

Por meio da personagem Bomston, Rousseau problematiza o tema, apresentando interpretações que nos são ainda correntes:
"A tristeza, o tédio, os arrependimentos, o desespero são dores pouco duráveis, que não se enraízam jamais na alma, e a experiência desmente sempre este sentimento de amargura que nos faz olhar nossas dores como eternas.
[...] violentas dores do corpo, quando são incuráveis, podem autorizar um homem a se dispor de si, pois estando todas as suas faculdades alienadas pela dor e sendo o mal sem remédio, ele não tem mais o uso nem de sua vontade nem de sua razão.

\footnotetext{
10 HUME, David. Do Suicídio. Tradução de Lívia Guimarães.

11 ROUSSEAU, Jean-Jacques. A Nova Heloísa. Tradução de Leonardo Meirelles Ribeiro (para todos os trechos de Rousseau citados).
} 
Ele cessa de ser homem antes de morrer e, tirando sua vida, não acaba senão por abandonar um corpo que o embaraça, no qual sua alma já não mais se encontra. Mas o mesmo não se passa com as dores da alma que, por mais vivas que sejam, trazem sempre seu remédio com elas. De fato, o que torna um mal qualquer intolerável? É sua duração." (ROUSSEAU, apud PUENTE, 2008, p. 140-1; itálicos nossos)

Discutir o suicídio é discutir o tempo, infinitamente. Assim, Rousseau, na resposta de Bomston, sofisma sobre os sofismas de um não defensor do suicídio, que considera a plausibilidade do ato para as dores do corpo, mas não para as da alma:

“É razoável aplicar remédios tão violentos aos males que se anulam por si mesmos? Para quem considera a constância e somente estima os anos pelo pouco que valem, dos dois modos de se libertar dos mesmos sofrimentos, qual deve ser preferido, a morte ou o tempo? Espere e será curado. Que quer mais?" (ROUSSEAU, apud PUENTE, 2008, p. 141-2)

E, apelando a um sentimento comum a todos nós:

"Sua morte não faz mal a ninguém? [...] Se existe uma pessoa no mundo que o tenha amado suficientemente para não querer sobreviver a você e que sente falta de sua felicidade para estar feliz, você pensa nada dever-lhe?" (ROUSSEAU, apud PUENTE, 2008, p. 142-3)

Dores do corpo, dores da alma. Estes conceitos determinam procedimentos médicos e legais, determinam muitas das avaliações que fazemos das pessoas com as quais nos relacionamos, determinam o modo como as pessoas são categorizadas psicológica e socialmente. Foucault estava atento ao fator determinante do discurso em campos como a medicina e a psiquiatria. Sobre a medicina, diz-nos: "Ela certamente possui uma estrutura muito mais sólida do que a psiquiatria, mas também está enraizada profundamente nas estruturas sociais" (FOUCAULT, 1979, p. 2). A questão aqui é: o que torna um enunciado científico verdadeiro? O que está envolvido nesta construção? 
“O que está em questão é o que rege os enunciados e a forma como estes se regem entre si para constituir um conjunto de proposições aceitáveis cientificamente e, consequentemente, susceptíveis de serem verificadas ou infirmadas por procedimentos científicos. Em suma, problema de regime, de política do enunciado científico. Neste nível não se trata de saber qual é o poder que age do exterior sobre a ciência, mas que efeitos de poder circulam entre os enunciados científicos; qual é seu regime interior de poder; como e por que em certos momentos ele se modifica de forma global." (FOUCAULT, 1979, p. 4)

Foucault assevera que a sua preocupação é com a questão de poder, não a simbólica, nem tampouco a semiótica. Mas, indubitavelmente, antes deste transporte político, há toda uma pavimentação hermenêutica, cristalizada nos discursos científicos e, esses sim, possuem poder. E determinam. Propomos, enquanto ferramenta de, se não destruição, ao menos, de desequilíbrio desse determinismo, uma hermenêutica existencial, que valorize a produção discursiva constante em nossas relações. A atuação da Medicina Narrativa pode, de alguma maneira, almejar fornecer essa ferramenta. Parafraseando Foucault, como o poder que se exerce sobre a saúde, a doença, sobre os pacientes, portanto, produziu o discurso 'verdadeiro' da medicina ${ }^{12} \mathrm{O}$ quanto este discurso verdadeiro ultrapassa a existência e a ética necessária para a nossa co-existência?

O historiador Fábio Henrique Lopes, em Suicídio \& Saber Médico: estratégias históricas de domínio, controle e intervenção no Brasil do século XIX, comenta:

“O suicídio, visto por muito tempo como pecado mortal, pôde ser perdoado ao ser patologizado. Uma visão muito invocada, principalmente pelos mais abastados, para evitar certas censuras, constrangimento para a família ou perda de privilégios. Podemos constatar que a loucura tem usos históricos para finalidades diversas, essas também históricas!" (LOPES, 2007, p. 68)

A obra de Lopes, fruto de sua pesquisa de doutorado, possui valiosas assunções para a Medicina Narrativa, pois, ao observar o desenvolvimento da medi-

12 A questão original de Foucault é: "Como o poder que se exerce sobre a loucura produziu o discurso 'verdadeiro' da psiquiatria?", in Microfísica do Poder. Org. e Trad. de Roberto Machado. Rio de Janeiro: Edições Graal, 1979: Pág. 230. 
cina dita social em nosso país, desvela os agentes de produção de discursos de saber/poder, questionando, como Foucault, suas ferramentas de "controle dos discursos", dentre os quais "destaca-se a rarefação dos sujeitos que falam, ou melhor, dos sujeitos que podem falar" (LOPES, 2007, p. 70). Sensível não só aos questionamentos sociopolíticos, Lopes pontua que

“[...] Neste jogo de regras e regimes de verdade, a única forma negada para pensar o suicídio foi a manifestação da liberdade humana. Assim, novos enunciados foram produzidos e divulgados como verdadeiros; os antigos foram proibidos e excluídos, transformados em anacrônicos." (LOPES, 2007, p. 69)

Curiosamente - ou não tão curiosamente assim -, a patologização do suicídio, tanto na Europa do século XIX, quanto em nosso país, que Ihe seguiu os passos, assume como um dos elementos a ser profilaticamente banido a literatura, mais especificamente, a literatura do período romântico: as turbulências da alma, que levavam à ruína dos corpos, estavam representadas em seus caracteres e precisavam ser amainadas pelos detentores das ferramentas de apaziguamento da sociedade.

Retornemos ao trecho de Lopes, acima: "Neste jogo de regras e regimes de verdade, a única forma negada para pensar o suicídio foi a manifestação da liberdade humana." Vimos, acima, de modo um tanto genealógico, um pequeno recorte da evolução tanto do tema, quanto da discussão filosófica sobre o suicídio - não chegamos, sequer, à discussão sobre a eutanásia e o suicídio assistido - e, neste recorte, o quanto da argumentação sobre este topos está influenciada por contextos políticos e sociais, inclusos, aí, ainda, os ditames espirituais de cada época. Quando falamos em liberdade, saltamos para a constituição do ethos, para a vivência de cada um de nós. É neste momento que apelamos a E. M. Cioran, filósofo que defendeu a morte de si do mesmo modo que Camus defendeu o absurdo: pela via da consciência e da revolta. Assim, para ele, "toda experiência que não se converte em volúpia é uma experiência falhada" (CIORAN, 1988, p. 176). Nesta via, viver a morte é compreendê-la como parte essencial de nossa vida. Como Sêneca, Cioran tem a dimensão de que, posto que sabemos de sua presença constante e podemos acessá-la, se assim o desejarmos, nossa existência torna-se plena, pois "a morte abre-nos ao verdadeiro sentido da nossa dimensão temporal, uma vez que, sem ela, ser no tempo nada significaria para 
nós, ou, quando muito, significaria o mesmo que ser na eternidade" (CIORAN, 1988, p. 176). Essa assunção é essencial, pois estabelece a diferença que há entre os homens e os deuses, diferença essa que faz com que esses nos invejem: existimos no devir, não na eternidade, e essa existência no devir fornece-nos toda a volúpia, como afirma Cioran, configurada em nosso viver. Assim, "cada ser é o seu sentimento da morte", e descarta-se "essa necessidade de fazer da morte um acidente ou um meio, de a reduzir à passagem, em vez de a considerar como uma presença" (CIORAN, 1988, p. 177).

Por fim - e, talvez, fora melhor que houvéssemos colocado isto inicialmente - por que estamos a discutir o suicídio? Por ser essa a questão maior que podemos nos propor, qual seja, se podemos ou não dispor de nossas vidas. $\mathrm{Ou}$, sob outra perspectiva: até que ponto cuidar da vida significa um caminho ético em direção à "vida boa" heideggeriana?

Aqui, estabelece-se uma questão de método, que define o modo como acessamos o ser e que Puente diagnosticou. A discussão sobre o suicídio

[a]o longo dos séculos se faz não só por meio de alguns argumentos, mas sobretudo por meio de algumas metáforas e imagens que podem ser refinadas, questionadas e mais dificilmente modificadas ou postas de lado com a finalidade de introduzir novas metáforas e imagens, ou mesmo, evidentemente, novos argumentos." (PUENTE, 2008, p. 11)

O ser está na narrativa, assim como as dores da alma estão em nossos corpos, assim como as dores do corpo percutem as nossas almas. A dificuldade de se tratar o topos do suicídio é tal que conduziu aqueles que sobre ele se debruçaram a recorrerem a metáforas e imagens, para realmente o ressignificar. Conclui-se, por derivação, também nesse assunto, a relevância do campo da Narrativa e Medicina, relevância essa oriunda daquela matéria que o nutre e é objeto dos estudos de narrativa em geral, que são as metáforas e imagens e a configuração do homem no tempo. Talvez se possa ousar colocar o suicídio como paradigma extremo do que não observamos diligentemente no corpo do conflito inerente à existência humana; entretanto, as contribuições epistemológicas da Narrativa e Medicina para a sociedade podem ser justamente trazer ao centro de nossos escrutínios aquilo que não se ouve, e tampouco se diz, - e que reside no âmbito dos processos miméticos presentes em nossas vidas -, e transmiti-lo ao âmbito 
do que se convenciona chamar de práticas e discursos de um dito saber, com o intuito de, pela narrativa e pelo constante exercício do questionamento filosófico, não os cerceá-los a uma única resposta, mas humanizá-los.

\section{Referências}

ARISTÓTELES. Ética Nicomáquea. Ética Eudemia. Tradução e notas de Julio Pallí Bonet. Madrid: Editorial Gredos, 1988. . Poética. Edição bilíngue. Tradução de Eudoro de Souza. São Paulo: Ars Poetica, 1993.

AYRES, José Ricardo de Carvalho Mesquita. O cuidado, os modos de ser (do) humano e as práticas de saúde. Saúde e Sociedade v.13, n.3, p.16-29, set-dez 2004.

BURDACH, Konrad. Faust un die Sorge. in Deutsche Vierteljahresschrift für Literaturwissenschaft und Geistesgeschichte, vol 1., 1923.

CAMUS, Albert. O Mito de Sísifo: Ensaio sobre o Absurdo. Tradução e apresentação de Mauro Gama. Editora Guanabara, 1989:26. Copyright by Éditions Gallimard, 1942.

CARELLI, Fabiana e MARQUES, Davina. How to change lives with words. In SANDBERG, Eric e SHEURER, Maren. Culture, experience, care: (re-)centring the patient. Oxford: Inter-Disciplinary Press, 2014, p. 47-56.

CIORAN, Emile. M. A Tentação de Existir. Tradução de Miguel Serras Pereira e Ana Luísa Faria. Relógio d'água Editores Lda. Lisboa, 1988.

DYE, Ellis, Sorge in Heidegger and in Goethe's Faust. in Goethe Yearbook, Volume 16, 2009, pp. 207-218. Published by North American Goethe Society.

DUARTE, Adriane da Silva. Cenas de reconhecimento na poesia grega. Campinas. Editora da Unicamp, 2012.

EUBEN, J. Peter. Greek Tragedy and Political Theory. Berkeley and Los Angeles. University of California Press, 1986.

GOETHE, Johann Wolfgang von. Fausto: uma tragédia. (parte 1 e 2). Tradução de Jenny Klabin Segall; apresentação, comentários e notas de Marcus Vinicius Mazzari. São Paulo: Ed. 34, 2007.

FOUCAULT, Michel. Microfísica do Poder. Organização e Tradução de Roberto Machado. Rio de Janeiro: Edições Graal, 1979.

HEIDEGGER, Martin. Ser e tempo. Tradução, organização, nota prévia, anexos e notas: Fausto Castilho. Campinas, SP: Editora da Unicamp; Petrópolis, RJ: Editora Vozes, 2012.

HERDER, Johann Gottfried Herder. Werke. Volkslieder, Übertragungen, Dichtungen. Heraus gegeben von Ulrich Gaier. Deutcher Klassiker Verlag, Frankfurt am Main, 1990. 
HUME, David. A Arte de Escrever Ensaio e outros ensaios (morais, políticos e literários). Seleção de Pedro Paulo Pimenta; tradução de Márcio Suzuki e Pedro Paulo Pimenta. São Paulo: Iluminuras, 2008.

KNOX, Bernard. The Heroic Temper. Berkeley and Los Angeles: University of California Press, 1966.

LOPES, Fábio Henrique. Suicídio \& Saber Médico: estratégias históricas de domínio, controle e intervenção no Brasil do século XIX. Rio de Janeiro: Ateliê, 2007.

MARX, Karl. Sobre o Suicídio (Peuchet: vom Selbstmord). Tradução de Rubens Enderle e Francisco Fontanella. São Paulo: Boitempo, 2006.

PLATÃO. Leyes. Livro IX, 873c2-d1. Tradução de Francisco Lisi. Madrid, Editorial Gredos, 1999.

PUENTE, Fernando Rey. Os filósofos e o suicídio. Belo Horizonte: Editora UFMG, 2008.

RICOEUR, Paul. O si-mesmo como outro. Trad. Ivone C. Benedetti. São Paulo: WMF Martins Fontes, 2014. . Tempo e narrativa. Trad. Constança Marcondes Cesar. Campinas: Papirus, 1994. . Tempo e Narrativa. Tradução de Claudia Berliner; revisão de Márcia V. Martinez de Aguiar; introdução de Hélio Salles Gentil. São Paulo: Editora WMF Martins Fontes, 2010.

SEGAL, Charles. Tragedy and Civilization. An Interpretation of Sophocles. Cambridge. Harvard University Press, 1981.

SÉNECA, Lúcio Aneu. Cartas a Lucílio. Tradução, prefácio e notas de J. A. Segurado e Campos. Lisboa: Fundação Calouste Gulbenkian, 1991.

SILVA, Rosely de Fátima. Do ato heroico à construção da noção de responsabilidade do agente moral, paralelos entre a Ética Nicomaqueia e a Poética de Aristóteles. Dissertação de Mestrado. Orientador Marco Antonio de Ávila Zingano. São Paulo: FFLCH, 2013.

SÓFOCLES. Aias. Apresentação e tradução de Flávio Ribeiro de Oliveira. São Paulo: Iluminuras, 2008.

. Édipo Rei de Sófocles. Tradução de Trajano Vieira; apresentação J. Guinsburg. São Paulo: Editora Perspectiva, 2004.

. Três Tragédias Gregas. Antígone, Prometeu Prisioneiro, Ájax. Tradução de Guilherme de Almeida, Trajano Vieira; com a participação especial de Haroldo de Campos. São Paulo: Editora Perspectiva, 2007.

Submetido em: 02-02-2016 Aprovado para publicação: 18-09-2016 